\title{
CLINICAL EVALUATION OF DENTIN HYPERSENSITIVITY TREATMENT WITH THE LOW INTENSITY GALLIUM- ALUMINUM-ARSENIDE LASER - AsGaAl
}

\author{
AVALIAÇÃO CLÍNICA DO TRATAMENTO DA HIPERESTESIA DENTINÁRIA COM LASER \\ DE BAIXA POTÊNCIA DE ARSENIATO DE GÁLIO-ALUMÍNIO - AsGaAl
}

Luciana Chucre GENTILE ${ }^{1}$, Sebastião Luiz Aguiar GREGHI²

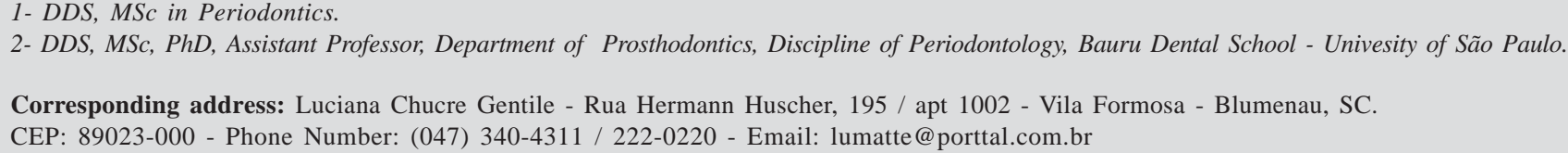

Received: August 06, 2002 - Modification: December 12, 2002 - Accepted: August 24, 2004

\begin{abstract}
Thed Ihe dentin hypersensitivity is a painful condition rather prevalent in the general population. There are several ways of treatment for such condition, including the low intensity lasers. The proposal of this study was to verify the effectiveness of the Gallium-Aluminum-Arsenide diode laser in the treatment of this painful condition, using a placebo as control.Materials and methods: Thirty-two patients were selected, 22 females and 10 males, with ages ranging from 20 to 52 years old. The 32 patients were randomly distributed into two groups, treated and control; the sample consisted of 68 teeth, 35 in the treated group and 33 in the control group. The treated group was exposed to six laser applications with intervals from 48 to 72 hours, and the control group received, as placebo, applications of a curing light. Results: A significant reduction was observed in the pain condition between the initial phase and after six laser applications; however, such reduction could also be observed for the control group exposed to the placebo. Conclusion: Therapy with the low intensity Gallium-Aluminum-Arsenide laser - AsGaAl induces a statistically significant reduction in the painful condition after each application and between the beginning and end of treatment, although there was no statistically significant difference between the treated group (laser) and the control group (placebo) at the end of treatment and after the mediate evaluation results (after 6 weeks), this way impairing the real measurement of laser effectiveness and placebo effect.

Uniterms: Dentinal hypersensitivity; Tooth, hyperesthesia; Laser treatment.
\end{abstract}

\begin{abstract}
RESUMO
A

hiperestesia dentinária trata-se de uma condição dolorosa bastante prevalente nas populações mundiais. Várias são as modalidades de tratamento para tal condição, entre elas, os lasers de baixa potência. A proposta deste estudo foi a de verificar a efetividade do laser de diodo de Arseniato de Gálio-Alumínio no tratamento desta condição dolorosa, utilizando-se um placebo como controle. Materiais e métodos: Foram selecionados 32 pacientes, 22 do sexo feminino e 10 do sexo masculino, com idades entre 20-52 anos. Os 32 pacientes foram distribuídos de maneira aleatória em dois grupos, um tratado e outro controle, um total de 68 dentes compôs a amostra, sendo que 35 compuseram o grupo tratado, e 33 o grupo controle. O grupo tratado foi submetido a seis sessões sucessivas de irradiações em intervalos de 48 a 72 horas, o grupo controle recebeu como placebo aplicações de luz do fotopolimerizador. Resultados: observou-se redução significativa na sensação dolorosa entre a fase inicial e após as seis sessões de tratamento com laser, porém tal redução, também pode ser observada para o grupo controle, submetido ao placebo. Conclusão: a terapia com laser de baixa potência de AsGaAl induz redução estatisticamente significante da sensação dolorosa, após cada uma das aplicações, e entre o início e o final do tratamento, embora não tenha havido, diferença estaticamente significante, ao final do tratamento e após a avaliação mediata dos resultados (após 6 semanas) entre o grupo tratado (laser) e o grupo controle (placebo); dificultando a mensuração real da efetividade do laser e do efeito placebo.

Unitermos: Hipersensibilidade dentinária; Hiperestesia dentinária; Laser, tratamento.
\end{abstract}




\section{INTRODUCTION}

Dentistry, as other health sectors, often faces a great trouble, which is pain, defined as "an unpleasant experience, sensory and emotional, associated to real or potential tissue damage"2.

Most orofacial pains are related to teeth and, among the odontalgias, dentin hypersensitivity is a painful condition highly prevalent in the general adult population ${ }^{3,9}$.

Dentine hypersensitivity is clinically described as a short and acute pain, originated from exposed dentine, as an answer to typical thermal, evaporable, tactile, osmotic or chemical stimulation, and that cannot be attributed to any other defect or dental pathology ${ }^{8,13,22}$.

This way, usual habits such as feeding, drinking and brushing teeth, which at normal dental conditions would not bring discomfort to a person, can become a chronic source of irritation ${ }^{3,5}$.

According to Dowell; $\mathrm{Addy}^{7}$ in 1983, dentin hypersensitivity is associated to exposure of the root surface to stimuli external to the oral cavity. Dentin exposure to the oral external environment is a result of enamel loss or gingival recession in combination with cement loss, with or without non-carious cervical lesions as abrasion and erosion ${ }^{3,5}$.

Some theories were proposed to explain the breaking out of such painful sensitivity, being the "Hydrodynamic Theory" the most accepted, which proposes that peripheral stimuli are transmitted to the pulp surface through fluid movement inside the dentin ducts, causing pain.

There are several options for treatment of this painful condition, including the low intensity lasers, whose performance is based on the increase of the excitability threshold of the free nervous terminations, causing an analgesic effect, besides stimulation of the pulp mesenchymal cells to differ in odontoblasts, with the purpose to produce reparative dentin ${ }^{10,21}$.

The proposal of this study was to verify the effectiveness of the Gallium-Aluminum-Arsenide diode laser in the treatment of this painful condition, evaluating the patients' immediate responses before and after each of the consecutive laser applications, using a placebo as control, and also comparing the achieved results with the initial condition, for both groups and between them.

\section{MATERIALS AND METHODS}

Based at the pertinent literature ${ }^{13,15,20}$, patients and teeth selection was made in accordance with the recommended inclusion criteria:

A) Patients selection:

- Complaint of sensitivity at the cervical part of the anterior and/or posterior teeth to current stimulus such as air, touch, sweet foods or brushing, with or without noncarious cervical lesions and with gingival recession, independent of their length or wideness;

- Good levels of oral hygiene, with an oral health condition that would allow precise diagnosis of dentin hypersensitivity;

- Absence of serious systemic and psychological diseases;

- Those using any analgesic or anti-inflammatory medicines were oriented to not make use of it 6 hours before hypersensitivity treatment.

B) Teeth selection:

- Exclusion of teeth presenting decays, cracks or fissures, large and unsatisfactory restorations, class $\mathrm{V}$ restorations, prosthetic elements and abutments of partial prosthesis under abnormal occlusion forces;

- Without periodontal cysts and increased mobility; in cases submitted to periodontal surgery, a minimum period of at least three months was respected before treatment of dentin hypersensitivity;

- Absence of occlusal trauma;

- Teeth should not have been submitted to dentin hypersensitivity treatment in the last six months.

Thirty-two patients were selected, being 22 females and 10 males, with ages ranging from 20 to 52 years old. The thirty-two patients were randomly distributed into two groups, treated and control; the sample consisted of 68 teeth, being 35 in the treated group and 33 in the control group. All patients participating in the study signed an Informed Consent Term, based on the Guidelines of the Ethics Committee of Bauru Dental School ${ }^{6}, 1998$.

All patients were submitted to an accurate anamnesis, in order to detect any systemic alteration, use of any medication, or psychological disturbances that could have been omitted at the initial report and that could be relevant for maintenance of the patient in the study. A second approach comprised questioning the patients about their current food habits, oral hygiene and about any periodontal treatments that could act as coadjutant factors triggering dentin hypersensitivity. However, no alteration regarding food habits was introduced, only concerning hygiene methods when the technique was considered traumatic.

C) Determination of dentin hypersensitivity patterns:

Each selected tooth of each patient received two stimuli, namely a tactile with a \#5 dental probe and an air jet, considered as a thermal-evaporative stimulus. The first stimulus consisted in investigating all lesion extension with the probe tip, which can lead to compression of the dentin, thus favoring motion of the dentin fluid, which activates the mechanoreceptors causing the painful sensation ${ }^{23}$. The second stimulus, the air-jet, was applied to the exposed dentin with an air syringe for one second, at room temperature and at a distance of $1 \mathrm{~cm}$ from the dentin surface $\mathrm{e}^{17,20,23}$. This stimulus can be considered a combination of thermal and evaporative stimuli, and this way two mechanisms operate to cause pain, namely the decrease in temperature at the dentin surface and fluid evaporation from some opened dentinal tubules, activating the hydrodynamic forces at the dentinal tubules and stimulating the painful sensation ${ }^{17}$.

An interval was allowed between the stimuli application, which was enough to avoid interferences between them. The stimulus considered as most severe was used as a last option, in this case the thermal-evaporative stimulation, in 
agreement with the literature ${ }^{11,14}$.

Measurement of sensitivity was performed after each stimulus by a Visual Analogue Scale, which consists of a 10-cm long line, where the ends represent the pain limits the patient can suffer through an external stimulus; one end represents absence of discomfort and the other represents a severe discomfort caused by certain stimuli. Each time the patient is submitted to a stimulus, he or she was requested to point, at the interval from 0 to 10 , a number to correspond to the pain felt. The convenience of this type of scale is to allow demonstration of the pain intensity with absolute numbers or as a percentage of a maximum value ${ }^{11,20}$.

The treated group, with 16 patients adding up to 35 teeth with dentin hypersensitivity, was submitted to treatment with the low intensity Gallium-Aluminum-Arsenide diode Laser (AsGaAl). The technical characteristics of the equipment used are:

- Laser emitter: AsGaAl diode

- Constant power: $15 \mathrm{~mW}$

- Density of adjustable irradiated energy: from 0 to 15J/ $\mathrm{cm}^{2}$

- Wavelength: 670hm (visible in red)

- Area irradiated with the intraoral tip: $4 \mathrm{~mm}^{2}$

The teeth included in the treated group were submitted to the sequence of treatment established by Brugnera; Pinheiro ${ }^{4}$, in 1998:

a) prophylaxis of the region with rubber cup, when possible; if prophylaxis was not possible due to sensitivity, a slightly wet cotton ball was used;

b) drying with cotton rolls;

c) punctual application of the laser, that is, application at 3 points (distal, central and mesial), and with the intraoral tip positioned perpendicular to the dentin surface.

The laser dosage applied to each tooth was $4 \mathrm{~J} / \mathrm{cm}^{2}$ for a predetermined time of $2 \mathrm{~min}$, according to calibration of the laser device ${ }^{18}$.

With regard to the control group, also composed of 16 patients adding up to 33 teeth with dentin hypersensitivity, a curing light was used as a placebo; each dentin surface was exposed to the curing light for 30 seconds. The teeth in the control group were also submitted to items a and b described above; a wood tongue depressor was placed over the sensitive area to avoid possible effects from heat produced by the curing light on the pulp tissue.

It should be mentioned that patient from both treated and control groups was submitted to six sessions for treatment of hypersensitivity, with intervals from 48 to 72 hours. The number of sessions and the intervals between the applications were performed as indicated by the manufacturer of the Low Intensity Laser device.

The painful sensation was measured previously to each one of the six sessions and immediately after treatment, for each stimulus applied, for both groups.

After the six applications, the patients were called back for reevaluation after six to eight weeks; this is the accepted time for evaluation of effectiveness, at short rate, of chemical desensitizers ${ }^{11}$. The tactile and thermal-evaporative tests were made again at the teeth submitted to treatment with the AsGaAl Laser or in the control group in which the placebo was used, the results being recorded once more in a Visual Analogue Scale.

All collected measurements, from the first until the reevaluation session, were converted in numbers for posterior statistical analysis.

According to Kaufman; Kleinberg ${ }^{15}$, in 1994, nonparametric tests must be used when two groups are compared, to check if there are significant differences between the analyzed groups. Thus, Wilcoxon and MannWhitney non-parametric tests were used to verify if there was pain reduction after each application, from the beginning to the end of treatment, besides comparison between the mean painful sensation of the treated and control groups. The significance level adopted was $5 \%(\mathrm{p}=0.05)$ for all tests.

\section{RESULTS}

Figures 1 and 2 represent the means obtained from painful sensation to tactile and thermal-evaporative stimuli, from the initial evaluation (Pre1) to the mediate evaluation (ME), effected 6 weeks after the last application (Post6) for both groups.

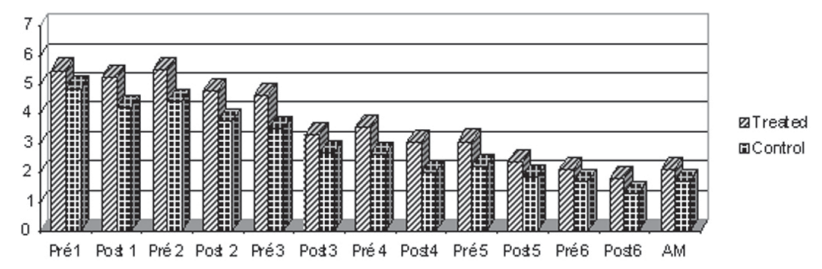

FIGURE 1- Mean pain for treated and control groups with tactile stimulus

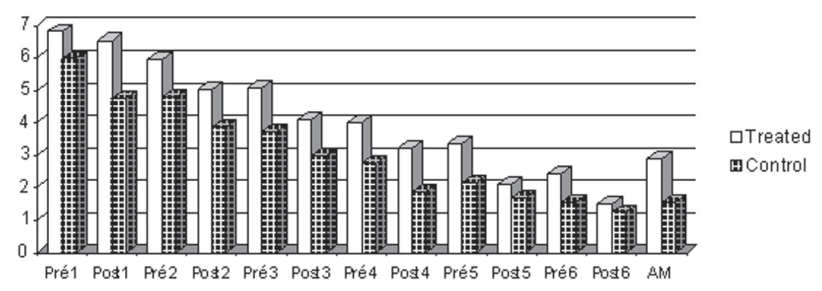

FIGURE 2- Mean pain for treated and control groups with thermal-evaporative stimulus

Application of Wilcoxon non-parametric test allowed comparison between the mean painful sensations triggered by the tactile and thermal-evaporative stimuli since the beginning of the study, when the sensations previous to the first application (Pre1) were recorded until the means obtained immediately after the last application (Post6), for both groups. A significant reduction was observed in the pain condition between the initial phase and after the six laser applications; however, such reduction was also observed for the control group, exposed to the placebo. 
The Mann-Whitney test was applied for evaluation of the difference between the value obtained immediately after the last application (Post6) and the initial value of the painful sensations (Pre1), for both stimuli used at the study, evidencing that there was no statistically significant difference in pain reduction between treated and control groups. The same was verified when comparing the results obtained at the mediate evaluation, which took place 6 weeks after last application, with the initial results (Pre1).

\section{DISCUSSION}

Utilization of low intensity lasers in the oral cavity has been of great applicability in cases of post-surgical pain, dentin hypersensitivity, angular cheilitis, aphthae and common herpes, besides promoting a faster dentin formation; however, the exact mechanism of its biostimulating action has not yet been completely determined in the literature ${ }^{21,24}$.

Studies with the low intensity laser in Dentistry have presented stimulating results, mainly with the HeNe and AsGaAl lasers, but such studies are usually poorly controlled and reported in an incomplete way ${ }^{1}$.

The present study tried to verify the effectiveness of the low intensity Gallium-Aluminum-Arsenide laser irradiation for reduction or remission of dentin hypersensitivity.

Clinically the patients demonstrated, at each session, relief of painful sensation when exposed to the hydrodynamic stimuli, also describing relief at daily stimuli such as contact of the exposed dentin surface with icy water, acidic foods, sweet foods and even toothbrushing.

Statistically, the means obtained during the applications for the group treated with the low intensity AsGaAl laser and for the control group where the placebo was used showed significant gradual reduction in pain condition, simultaneous to irradiation, for both hydrodynamic stimuli,

TABLE 1- Comparison between the mean painful sensation between the beginning and end of treatment for both treated and control groups

Pre 1 and Post 6 Comparison

\begin{tabular}{lccc} 
Stimuli & Groups & $\mathbf{z}$ & $\mathbf{p}$ \\
\hline & Treated & 5.159 & $<0.0001^{*}$ \\
Tactile & Control & 4.815 & $<0.0001^{*}$ \\
& Treated & 5.159 & $<0.0001^{*}$ \\
Thermal-evaporative & Control & 5.011 & $<0.0001^{*}$ \\
\hline
\end{tabular}

* statistically significant difference.

TABLE 2- Representation of the comparative results between Treated and Control groups concerning painful sensation reduction

\begin{tabular}{|c|c|c|c|c|c|c|c|}
\hline \multirow[t]{2}{*}{ Stimuli } & \multirow[t]{2}{*}{ Phase } & \multicolumn{2}{|c|}{ Treated } & \multicolumn{2}{|c|}{ Control } & \multicolumn{2}{|c|}{$\mathbf{p}$} \\
\hline & & $x$ & sd & $\mathbf{x}$ & sd & & \\
\hline & Pós6 - Pré1 & -3.67 & 1.72 & -3.60 & 2.60 & 557.0 & $0.801 \mathrm{~ns}$ \\
\hline \multicolumn{8}{|l|}{ Tactile } \\
\hline & AM-Pré1 & -3.36 & 2.14 & -3.17 & 2.97 & 570.5 & $0.931 \mathrm{~ns}$ \\
\hline & Pós6 - Pré1 & -5.33 & 1.97 & -4.73 & 2.24 & 509.5 & 0.403 ns \\
\hline \multicolumn{8}{|c|}{ Thermal-evaporative } \\
\hline & AM-Pré1 & -3.91 & 2.69 & -4.42 & 2.68 & 536.5 & $0.614 \mathrm{~ns}$ \\
\hline
\end{tabular}

ns -non-statistically significant difference. 
one tactile and one thermal-evaporative.

Statistical and clinical results revealed that pain reduction occurred for both stimuli, tactile and thermal-evaporative. The initial results, clinical and in absolute values, demonstrated more pronounced painful response to thermalevaporative stimulus when compared to tactile stimulus, and that the pain reduction pattern during treatment, as well as at evaluation after the last session presented a more positive response to tactile stimulus than to thermalevaporative stimulus in a general way.

Such results differ from the findings of Gerschman; Ruben; Gebart-Eaglemont ${ }^{10}$, in 1994, that using the AsGaAl laser with wavelength of $830 \mathrm{hm}$, applications of $1.8 \mathrm{~J} / \mathrm{cm}^{2}$ at intervals of 1, 2 and 8 weeks verified a more accentuated reduction of pain using the thermal-evaporative stimulus, instead of the tactile stimulus.

Wakabayashi, Matsumoto ${ }^{26}$, in 1988, exposed 130 teeth with dentin hypersensitivity to air-jet to a treatment with the AsGaAl laser (wavelength of $780 \mathrm{hm}, \mathrm{Cw}, 30 \mathrm{~mW}$ ) when the hypersensitive dentine surfaces were irradiated for 30 to 180 seconds, and the results obtained showed $98 \%$ reduction at dentin hypersensitivity, while in the control group, not exposed to irradiation, the reduction was $19 \%$.

Manton, Renton-Haper, Midda ${ }^{19}$, in 1992, in a comparative study between the Nd:YAG and the low intensity GaAs lasers for dentine hypersensitivity treatment, verified reduction in the painful response to a thermal-evaporative stimulus, finding that the group treated with the Nd:YAG laser and reevaluated at 3 and 28 days after treatment took longer to respond to the stimulus with the air-jet than the group treated with the GaAs laser, whose result approached very much the one observed at the control group that did not receive any treatment.

Groth $^{12}$, in 1993, evaluated the dentin hypersensitivity reduction in 25 teeth irradiated with laser. The device employed was a low intensity AsGaAl laser with wavelength of $790 \mathrm{hm}$ and $30 \mathrm{~mW}$ potency. The hypersensitive teeth were exposed to the thermal-evaporative stimulus with an air-jet for 5 seconds, being afterwards irradiated for 4 minutes; this procedure was repeated three times at 72-hour intervals. The variation in the degree of dentin hypersensitivity was evaluated for a period of 15 and 30 days after the first irradiation. The author observed, at the end of the reevaluations, a statistically significant reduction in painful sensation to the thermal-evaporative stimulus.

Although the results obtained by the present study are in agreement with Wakabayashi, Matsumoto ${ }^{26}$, in 1988 and with Groth ${ }^{12}$, in 1993 concerning the painful sensation reduction, it is known that the precise mechanisms of the low intensity laser action for cases of dentin hypersensitivity cases are not well clarified.

Wider-Smith ${ }^{28}$, in 1998, when evaluating the effectiveness of the low intensity HeNe laser at treatment of the dentin hypersensitivity obtained very poor results when comparing to conventional therapies that promote physical obstruction of the dentinal tubules, obtaining remission of dentin hypersensitivity in only 4 of a total of 97 treated teeth. The referred author believes that lasers with wavelengths from
632.8 to $780 \mathrm{hm}$ are unable to produce any alteration on the tooth mineralized surface, or pulp alterations that accelerate the cellular differentiation process.

In agreement with the above mentioned study, Kimura, Wilder-Smith, Matsumoto ${ }^{16}$, in 2000, evaluated the low intensity AsGaAl laser action with 3 wavelengths, 780, 830, $900 \mathrm{hm}$, and stated that only after a wavelength of $830 \mathrm{hm}$ it is possible to transmit the laser energy through enamel and dentin, reaching the pulp tissue. Although the above mentioned studies do not present results that support conclusions concerning the ideal wavelength, it should be mentioned that the wavelength of the device used in this study was $670 \mathrm{hm}$, and the obtained results showed a clinically relevant reduction in pain sensation, although it cannot be stated if it was completely due to the laser. However, there are no absolute scientific proofs of which would be the most adequate wavelength, as well as timing of application, quantity of joules to be applied, number of applications and the interval between them.

The ideal standards for use of the low intensity lasers, both Hene and the AsGaAl, are difficult to establish, as important factors must be considered, such as severity of the pain sensation with the stimulus, exposure area of the root surface, degree of loss of root structure and the individual response of each patient to treatment. This last aspect is very critical because, as people react differently to the several types of dentin hypersensitivity treatments, one can also assume that, among all these multiple variants, there is a limit from which treatment can be stimulating. Therefore, defining patterns for laser utilization is still questionable, considering that the biological variability between patients can be great.

An important aspect to be considered in the present results is that, although a clinical and statistically significant reduction was observed in dentin sensitivity for the treated group, a significant reduction was also observed for the control group that received application of curing light as a placebo, a condition attributed to the so-called "placebo effect".

According to West, et al. ${ }^{27}$, in 1997, the placebo effect is commonly verified in dentin hypersensitivity studies, being characterized as an answer to the interventions and not to any particular mechanism of action.

Such effect consists of a complex mixing of physiological and psychological interaction, depending considerably of a positive relation between professional and patient, with both parts believing in the treatment validity and wishing relief of the painful symptomatology. A positive relation between professional and patient can motivate the patient to obtain relief of the painful sensation; besides, this favorable emotional behavior can activate the system of pain inhibition of the organism, leading to release of endorphins by the central nervous system and this way controlling the painful stimulus at the periphery ${ }^{16,25}$.

Anyway, the achievement of reduction of dentin hypersensitivity in both treated and control groups, this way corroborating the results of several studies in the literature where a placebo was not used as a control, leaves 
some controversy regarding the effectiveness of use of the low intensity lasers for this therapeutics, opening space for new research works.

\section{CONCLUSIONS}

- There was statistically significant reduction of painful sensation after each laser application and between the beginning and the end of treatment, although there was no statistically significant difference between the treated group (laser) and the control group (placebo) at the end of treatment and after the mediate evaluation results (after 6 weeks), this way impairing the real measurement of laser effectiveness and placebo effect.

- Caution is advised when evaluating the results obtained by the applied therapy, considering the placebo effect, as the results obtained for the control group are very similar to those obtained for the treated group. Such fact implies at the need of controls for longer periods of time after the end of applications, when maybe the placebo effect would dissipate and then it would be possible to verify the real laser effect more clearly.

\section{REFERENCES}

1- Basford JR. Low intensity laser therapy: still not an established clinical tool. Lasers Surg Med 1995;16 (4):331-42,

2- Bell WE. Dores orofaciais - classificação, diagnóstico, tratamento. Rio de Janeiro: Quintenssece; 1991.

3- Bissada, NF. Symptomatology and clinical features of hypersensitive teeth. Arch Oral Biol 1994;39: 31S-2S, Supplement.

4- Brugnera AJ, Pinheiro, ALB. Lasers na odontologia moderna. São Paulo, Pancast; 1998.

5- Collaert B, Fischer C. Dentine hypersensitivity: a review. Endod Dent Traumat 1991 Feb; 7(1):145-52.

6- Comitê de ética em pesquisa da Faculdade de Odontologia de Bauru, Bauru; 1998.

7- Dowell P, Addy M. Dentine hypersensitivity - a review. J Clin Periodontol 1983; 10(4):341-50.

8- Dowell P, Addy M, Dummer P. Dentin hypersensitivity: aetiology, diferential diagnosis and management. Br J Dent 1985; 158(9):92-6.

9- Flynn J, Galloway R, Orchardson, R. The incidence of hypersensitive teeth in the West of Scotland. J Dent 1985; 13(3):230-

10- Gerschman JA, Ruben J, Gebart-Eaglemont, J. Low level laser therapy for dentinal tooth hypersensitivity. Aust Dent J 1994 Dec; 39 (6): $353-7$

11- Gillam DG, Orchardson R, Närhi MVO, Kontturi-Närhi V. Present and future methods for the evaluation of pain associated with dentine hypersensitivity. In: Addy M. et al.Tooth wear and sensitivity. London, Martin Dunitz, 2000. Cap.25, p.283-97.
12- Groth EB. Contribuição para o estudo da aplicação do laser de baixa potência de GaAlAs no tratamento da hipersensibilidade dentinária. São Paulo; 1993. 60p. Dissertação (Mestrado) - Faculdade de Odontologia de São Paulo, Universidade de São Paulo.

13- Holland GR, Närhi MN, Addy M, Gangarosa L, Orchardson R. Guidelines for the design and conduct of clinical trials on dentine hypersensitivity. J Clin Periodontol 1997; 24(11) 808-13.

14- Ide M, Wilson RF, Ashley, FP. The reproducibility of methods of assessment for cervical dentine hypersensitivity. J Clin Periodontol 2001 Jan; 2 (1):16-22.

15- Kaufman HW, Kleinberg, I. Design and statistical aspects of the management of clinical trials to assess antihypersensitivity product efficacy. Arch Oral Biol1994; 39: 97S-100S, Supplement.

16- Kimura Y, Wilder-Smith P, Matsumoto K. Treatment of dentine hypersensitivity by lasers: a review. J Clin Periodontol 2000 Oct; 2 (10) $715-21$.

17- Krauser JT. Hypersensitive teeth. Part II: treatment. J Prosthet Dent 1986;56 (3):307-11.

18- Laser - alta tecnologia em baixa potência. s.ed., São Paulo. s.d.

19- Manton S, Renton-Harper P, Midda M. Laser treatment of dentine hypersensitivity. J Dent Res 1992;71:608. /Abstract n. 742./

20- MARTINELI ACBF. Avaliação da hiperestesia dentinária após tratamento comdiferentes formulações à base de oxalato de potássio, utilizando-se um placebo como controle. Bauru; 1999. 162p. Dissertação (Mestrado) Faculdade de Odontologia de Bauru, Universidade de São Paulo.

21- Mello JB, Mello GPS. Laser em odontologia. São Paulo: Ed. Santos; 2001.

22- Orchardson R, Collins WJN. Clinical features of hypersensitive teeth. Br J Dent 1987;162(11):253-6.

23- Pashley DH. Mechanism of dentin sensitivity. Dent Clin N Amer 1990;34(3): 449-73.

24- Ribeiro MS. Curso clínico de laser em odontologia, apostila de curso FUNDECTO-USP, São Paulo; 2001.

25- Trowbridge HO, Silver DR. A review of current approaches to inoffice management of tooth hypersensitivity. Dent. Clin. N. Amer 1990;34(3):561-81

26- Wakabayashi H, Matsumoto K. Treatmentof dentine hypersensitivity by GaAlAs soft laser irradiation. J Dent Res 1988, 67:182./ Abstract n.554/

27- West NX, Addy M, Jackson RJ, Ridge DB. Dentine hypersensitivity and the placebo response: a comparison of the effect of strontium acetate, potassium nitrate and fluoride toothpastes. J Clin Periodontol 1997;24(4):209-15.

28- Wilder-Smith P. The soft laser: therapeutic tool or popular placebo? Oral Surg Oral Med Oral Pathol Oral Radiol Endod 1988;66(6):654-8 